\title{
WOOD CONSUMPTION RATES OF FOREST SPECIES BY SUBTERRANEAN TERMITES (ISOPTERA) UNDER FIELD CONDITIONS ${ }^{1}$
}

\author{
Regina Célia Gonçalves Peralta ${ }^{2}$, Eurípedes Barsanulfo Menezes ${ }^{2}$, Acácio Geraldo Carvalho ${ }^{3}$ and Elen de Lima \\ Aguiar-Menezes ${ }^{4}$
}

\begin{abstract}
Termites are well -known for their capacity to damage and destroy wood and wood products of all kinds in the tropics and subtropics. A field test was undertaken to evaluate variations in wood consumption of Pinus sp. and three species of Eucalyptus by subterranean termites. The test consisted of wooden stakes of each species being initially submitted to water immersion for $0,24,48$ and $72 \mathrm{~h}$, and buried in the ground to natural infestation by subterranean termites for an exposure period of 30, 45 and 60 days. Three species of subterranean termites were identified: Heterotermes longiceps (Snyder), Coptotermes gestroi (Wasmann) (Isoptera: Rhinotermitidae), and Nasutitermes jaraguae (Holmgren) (Isoptera: Termitidae). This is the first record of occurrence of $H$. longiceps in the state of Rio de Janeiro. Although the wood-consumption rates were not correlated significantly with their wood densities, there was a tendency of the softwoods (E. robusta and Pinus sp.) to be more consumed by subterranean termites than the woods of intermediate hardness (E. pellita and E. urophylla). Among the eucalyptus, E. robusta showed to be more susceptible to attack by subterranean termites than E. pellita and E. urophylla.
\end{abstract}

Key words: Insecta, Rhinotermitidae, Termitidae, termite-attack wood resistance, Eucalyptus, Pinus.

\section{TAXAS DE CONSUMO DE MADEIRA DE ESPÉCIES FLORESTAIS POR TÉRMITAS SUBTERRÂNEOS (ISOPTERA) SOB CONDIÇÕES DE CAMPO}

\begin{abstract}
RESUMO - Térmitas são bem conhecidos por sua capacidade de danificar e destruir madeira e produtos derivados nos trópicos e subtrópicos. Um teste de campo foi realizado para avaliar as diferenças no consumo de madeira de Pinus sp. e de três espécies de Eucalyptus por térmitas subterrâneos. O teste consistiu de estacas de madeira de cada espécie, que foram inicialmente submetidas à imersão em água por 0, 24, 48 e 72 horas, e enterradas no solo para infestação natural por térmitas subterrâneos por um período de 30, 45 e 60 dias. Três espécies de térmitas subterrâneos foram identificadas: Heterotermes longiceps (Snyder), Coptotermes gestroi (Wasmann) (Isoptera: Rhinotermitidae), e Nasutitermes jaraguae (Holmgren) (Isoptera:Termitidae). Este é o primeiro registro da ocorrência de H. longiceps no estado do Rio de Janeiro. Embora a taxa de consumo de madeira não se correlacionou significativamente com a densidade da madeira, houve uma tendência das madeiras macias (E. robusta e Pinus sp.) serem mais consumidas do que as madeiras duras (E. pellita e E. urophylla). Entre os eucaliptos, E. robusta mostrou ser mais susceptível ao ataque de térmitas subterrâneos do que E. pellita e E. urophylla.
\end{abstract}

Palavras-chave: Insecta, Rhinotermitidae, Termitidae, resistência da madeira a térmitas, Eucalyptus, Pinus.

\section{INTRODUCTION}

Termites are responsible for much of the degradation of wood and other cellulose material in the terrestrial environment, mainly in the tropics and subtropics
(Coulson \& Lund, 1973). Cellulose being the principal food of termites, wood and wood products, such as paper, fabrics and wood structures are avidly consumed and destroyed by them, and hence, a constant effort is directed toward their control.

1 Recebido para publicação em 26.2.2002 e aceito para publicação em 30.4.2004.

2 Universidade Federal Rural do Rio de Janeiro - UFRRJ, Instituto de Biologia, CIMPUR “CRG”, BR 465, Km 7, 23890-000 Seropédica-RJ, <regina.peralta@bol.com.br>, <ebmen@uol.com.br>; ${ }^{3}$ Universidade Federal Rural do Rio de Janeiro, Instituto de Floresta, Departamento de Produtos Florestais, <acácio@ufrrj.br>; ${ }^{4}$ Embrapa Agrobiologia, BR 465, Km 7, Caixa Postal 74505, 23890-000 Seropédica-RJ, <menezes@ cnpab.embrapa.br>. 
Field and laboratory tests indicated that some woods are not resistant, but others are resistant to their attack (e.g. Skolmen, 1974; Bultman \& Southwell, 1976; Bultman et al., 1979; Abreu \& Silva, 2000).

Susceptible wooden material may be protected from termites by the use of toxic or repellent chemicals. However, many wood chemicals will be unacceptable in the future because of their potentially adverse environmental effects. The plantation of forest species and the use of woods having natural resistance to termites offer an alternative for the use of chemicals products. These studies are particularly suited to sustainable rural development, forestation and reforestation programs.

Factors affecting wood consumption by termites are numerous and complexly related. Among the most important of these factors are wood species and hardness, presence of toxic substances, feeding inhibitors or deterrents, presence or absence of fungi and degree of fungal decay, moisture content of wood and soil (Smythe et al., 1971; Carter \& Smythe, 1974, Nagnan \& Clement, 1990). Our concern in this study work is with wood species and densities, which influence the termite's ability to fragment the wood mechanically with its mandibles. Correlations between wood density and termite-attack resistance have been reported in previous studies (Behr et al., 1972; Coulson \& Lund, 1973; Bultman et al., 1979; Abreu \& Silva, 2000).

The experiments were carried out in a field environment to compare the subterranean termite wood consumption rates considering four species (three Eucalyptus species and Pinus sp.). Eucalyptus is a fast growing species with climatic hardness, and desirable pulping properties (Malan, 1989). However, it is particularly susceptible to attack by termites (Atkinson et al., 1992).

\section{MATERIALAND METHODS}

The experiment was set up in July 2000 and ran for 60 days. It was carried out in a $2.000 \mathrm{~m}^{2}$ backyard garden plot in the residential area of the Universidade Federal Rural do Rio de Janeiro (UFRuralRJ) in Seropedica, RJ, at which two subterranean termite infestation foci (Heterotermes longiceps (Snyder) and Coptotermes gestroi (Wasmann) (Isoptera: Rhinotermitidae) were found (A and B - Fig. 1). This area was selected based on the studies carried out by BICALHO (2000). The city of Seropedica is located in southeastern Brazil at $22^{\circ} 46^{\prime} \mathrm{S}$ latitude, $43^{\circ} 41^{\prime} \mathrm{W}$ longitude and $33 \mathrm{~m}$ above sea level. The climate is defined as humid-warm, with a mean annual temperature of $22.7^{\circ} \mathrm{C}$, an yearly average rainfall of $1200 \mathrm{~mm}$, a dry winter and a rainy summer season (FIDERJ, 1976).

Wooden stakes, $5.0 \mathrm{~m}$ long with a diameter of $10.5 \mathrm{~cm}$, were supplied by the Department of Forest Products at the UFRuralRJ, and cut from heartwood or sapwood of 8-year-old trees of Pinus sp. and three species of Eucalyptus: E. pellita F. Muell. (red mahogany), E. urophylla S.T. Blake (Timor mountain gum), and E. robusta $\mathrm{Sm}$. (swamp mahogany).

To determine the wood density of each forest species, three wood disk samples, $3.5 \mathrm{~cm}$ thick with a diameter of $10.5 \mathrm{~cm}$, were cut from these stakes. The density was defined as mean dry weight divided by the mean volume of the wood samples, and expressed as grams per $\mathrm{cm}^{3}$. Each sample was cut into four pieces, and subsequently submerged in water contained in $18-\mathrm{L}$ plastic buckets for six weeks. Each sample was then submerged in a 1-L beaker, which was placed on an electronic weighing machine. The weights were recorded and referred to the volumes. The samples were ovendried at $100{ }^{\circ} \mathrm{C}$ for 4 days, placed in a dryer for 30 minutes, and weighed to determine their dry weights. The volume was obtained by the water immersion following the method of Vital (1984); each method was explained above. Based on the density values, the forest species were classified as softwood $\left(\geq 0.50 \mathrm{~g} / \mathrm{cm}^{3}\right)$, wood of intermediate hardness $\left(0.51-0.72 \mathrm{~g} / \mathrm{cm}^{3}\right)$, or hardwood $\left(\leq 0.73 \mathrm{~g} / \mathrm{cm}^{3}\right)$, according to MELO et al. (1990).

The experiment test consisted of 240 stakes of each species which were driven vertically into the soil. The $2.5 \times 3 \times 25 \mathrm{~cm}$ stakes were cut from the same wood pieces as those used for determining the density. Each stake constituted an experimental unit. They were installed in the field following a completely randomized design with a $4 \times 4$ factorial selection of treatment, with five replicates.

Before testing, the top of the eucalyptus stakes was painted in different colors to identify the wood species: black (E. pellita), white (E. robusta) and green (E. urophylla). All stakes were oven-dried at $100{ }^{\circ} \mathrm{C}$ for $24 \mathrm{~h}$, placed in a dryer for another half hour, and then weighed in order to determine the initial weights. Afterwards, the stakes were submerged in water contained in 35-L plastic buckets for different immersion 
periods: 0, 24, 48 and 72 hours. These periods were marked down on the respective stakes, which were then installed in an area of $260 \mathrm{~m}^{2}$ containing the termite infestation foci A and B (Figure 1). with approximately $1 / 5$ of the total length protruded above ground level, the stakes were planted in groups of 4 (one of each forest species) at ca. $0.5 \mathrm{~m}$ intervals. They were exposed in the field for a period of 30, 45 and 60 days after the installation, and left undisturbed during these exposure periods. At the end of each period, the stakes were removed for inspection. A visual examination of the stakes was made during each exposure period to record the degree of subterranean termite infestation. Termite specimens were collected, preserved in labeled vials filled with $80 \%$ alcohol and sent to Prof. Reginaldo Constantino (Unb, Department of Zoology, Brasília, DF, Brazil) for identification. The damaged stakes were taken to the laboratory to determine the final weight in order to calculate wood consumption. Wood consumption percentage was also calculated.

Wood consumption rates were expressed as weight of wood removed by termites over a period of time. The wood removed was defined as initial minus final stake weights with test duration periods equivalent to the time during which the stakes were exposed to termites in the field (30, 45 and 60 days).

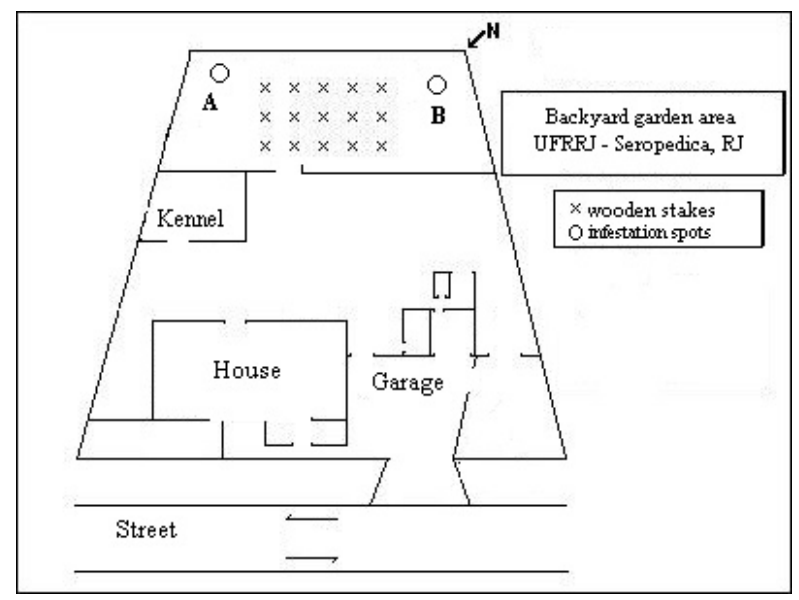

Figure 1 - Experimental field in the residential area of the Universidade Federal Rural do Rio de Janeiro in Seropedica, RJ.

Figura 1 - Campo experimental na área residencial da Universidade Federal Rural do Rio de Janeiro em Seropédica, RJ.
Differences in wood-consumption data among the forest species stake water immersion times, and the exposure period of the stakes in the field were compared using analysis of variance (ANOVA) and Fisher's test $(\alpha=0.05)$. Average results were tested for significance at $5 \%$ level, and separated using the Tukey's test. Pearson's linear correlation coefficient (r) was used to determine the relationship between mean wood-consumption rates and mean wood densities. The statistical tests were performed using Sisvar v 4.3 software.

\section{RESULTSAND DISCUSSION}

The wooden stakes were principally infested by the following subterranean termite species: Heterotermes longiceps (Snyder) and Coptotermes gestroi (Wasmann) (Isoptera: Rhinotermitidae). The first species was collected 30 days after the experiment was started, while $C$. gestroi occurred during the 45- and 60-day exposure periods. This suggests that agonistic response may have occurred between colonies of these two species, which probably resulted in a takeover of the $H$. longiceps foraging site by $C$. gestroi. Interspecificity encounters among termite colonies resulting in agonistic response were observed by Springhetti \& Amorelli (1982) and Thorne (1982). Field observation by Su \& Scheffrahn (1988) revealed two incidents in which foraging sites of Reticulitermes flavipes (Kollar) were taken over by Coptotermes formosanus Shiraki. This is the first recorded occurrence of $H$. longiceps in the state of Rio de Janeiro (Constantino, 2001).

Nasutitermes jaraguae (Holmgren) (Isoptera: Termitidae) also occurred at the end of the period of experimentation, i.e., at 60 days, but they attacked different stakes from those damaged by $C$. gestroi.

The wood-consumption rates on the stakes of the three eucalyptus species did not differ significantly among the times of immersion in water until 60 days after the experiment was installed (Table 1). Probably most of the stakes were only superficially damaged or not damaged at all during the 60 days of the experiment.

However, it was observed that the woodconsumption rates of Pinus stakes immersed in water for 48 hours were significantly higher than the other treatments at 30 and 45 days after the installation of the experiment $(18.83 \pm 5.8 \mathrm{~g}$ and $50.02 \pm 5.8 \mathrm{~g}$, respectively) (Table 2). We also observed that the wood-consumption

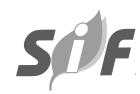


Table 1 - Subterranean termites consumption rates (g) for wood immersged in water for $0,24,48$ and $72 \mathrm{~h}$, at 30,45 and 60 days after the installation of the experiment

Quadro 1 - Consumo (em gramas) por térmitas subterrâneos de amostras de madeira imersa em água por 0, 24 , 48 e 72 horas, em 30, 45 e 60 dias após a instalação do experimento

\begin{tabular}{|c|c|c|c|c|}
\hline \multirow{2}{*}{ Forest species } & \multirow{2}{*}{$\begin{array}{c}\text { Time of immersion of } \\
\text { stakes in water }(\mathrm{h})\end{array}$} & \multicolumn{3}{|c|}{ Mean wood consumption rate/exposure period (g/day) ${ }^{\underline{1} /}$} \\
\cline { 3 - 5 } & 0 & 30 & 45 & 60 \\
\hline \multirow{3}{*}{ Eucalyptus robusta } & 24 & $1.47 \mathrm{a} \pm 3.8$ & $6.42 \mathrm{a} \pm 3.8$ & $14.62 \mathrm{a} \pm 3.8$ \\
& 48 & $2.82 \mathrm{a} \pm 3.8$ & $1.99 \mathrm{a} \pm 3.8$ & $0.00 \mathrm{a} \pm 3.8$ \\
& 72 & $3.00 \mathrm{a} \pm 3.8$ & $6.13 \mathrm{a} \pm 3.8$ & $0.73 \mathrm{a} \pm 3.8$ \\
& 0 & $10.95 \mathrm{a} \pm 3.6$ & $9.33 \mathrm{a} \pm 3.6$ & $13.09 \mathrm{a} \pm 3.6$ \\
Eucalyptus urophylla & 24 & $2.03 \mathrm{a} \pm 3.6$ & $0.00 \mathrm{a} \pm 3.6$ & $3.49 \mathrm{a} \pm 3.6$ \\
& 48 & $3.34 \mathrm{a} \pm 3.6$ & $21.62 \mathrm{a} \pm 3.6$ & $0.00 \mathrm{a} \pm 3.6$ \\
& 72 & $1.99 \mathrm{a} \pm 3.6$ & $9.58 \mathrm{a} \pm 3.6$ & $12.72 \mathrm{a} \pm 3.6$ \\
\hline \multirow{3}{*}{ Eucalyptus pellita } & 0 & $7.93 \mathrm{a} \pm 6.1$ & $5.67 \mathrm{a} \pm 6.1$ & $0.00 \mathrm{a} \pm 6.1$ \\
& 24 & $4.71 \mathrm{a} \pm 6.1$ & $1.00 \mathrm{a} \pm 6.1$ & $0.00 \mathrm{a} \pm 6.1$ \\
& 48 & $0.00 \mathrm{a} \pm 6.1$ & $3.03 \mathrm{a} \pm 6.1$ & $0.00 \mathrm{a} \pm 6.1$ \\
& 72 & $\mathrm{a} \pm 6.1$ & $0.00 \mathrm{a} \pm 6.1$ \\
\hline
\end{tabular}

${ }^{1 /}$ Averages within a column followed by the same letter are not significantly different, as gauged by Tukey's test $(\mathrm{P} \leq 0.05)$.

rate of Eucalyptus stakes by $C$. gestroi was lower than that of Pinus stakes, with the maximum value of $21.62 \pm$ $3.6 \mathrm{~g} \mathrm{~g}$ at 45 -day exposure period (Table 1). The values were much closer to those found in Coptotermes lacteus (Froggatt): $23.3 \pm 5.7 \mathrm{~g}$ to Eucalyptus regnans, and $29.1 \pm 5.5 \mathrm{~g}$ to Eucalyptus delegatensis after 56 days (Lenz, 1983).

Using the wood classification method proposed by Melo et al. (1990), E. robusta and Pinus sp. were classified as softwood (0.41 and $0.43 \mathrm{~g} / \mathrm{cm}^{3}$, respectively), and E. pellita and E. urophylla as wood of intermediate hardness (0.53 and $0.68 \mathrm{~g} / \mathrm{cm}^{3}$, respectively).

Considering wood density alone as a feeding determinant, the wood-consumption rates for the four forest species, there was a tendency for the softwoods (E. robusta and Pinus sp.) to be more consumed by subterranean termites than the woods of intermediate hardness (E. pellita and E. urophylla). Woodconsumption of Pinus sp. and E. robusta achieved the rates of $50.02 \pm 5.8 \mathrm{~g}$ and $14.62 \pm 3.8 \mathrm{~g} \mathrm{~g}$ at 45 and 60 days after the experiment was started, respectively (Tables 2 and 1). The greatest wood-consumption rates of E. urophylla and E. pellita were $21.62 \pm 3.6 \mathrm{~g}$ and $7.71 \pm$ $6.1 \mathrm{~g}$ at 45 and 30 days after the installation of the stakes, respectively (Tables 1). Behr et al. (1972) showed that $R$. flavipes feeding was negatively correlated with wood hardness. Bultman et al. (1979) found a general inverse relationship between the hardness of the wood and the amount of $C$. formosanus damage it received, with the lighter, softer woods being more heavily damaged than heavier, harder woods. However, Waller et al. (1990) found that the wood densities of pine and mahogany $(0.52$ and $0.73 \mathrm{~g} / \mathrm{cm}^{3}$, respectively) did not affect the amount of wood consumed by C. formosanus.

One cannot consider wood density as the only factor which influences wood consumption by the Isoptera group. Some reports (Nagnan \& Clement, 1990; Lemaine et al., 1991; Scheffrahn, 1991; Grace, 1997) related that, in both laboratory and field tests, some antitermitic chemical compounds found in forest species like terpenoids and quinones acted as a natural repellent for these insects.

An analysis of Table 3 of the subterranean termite consumption rates for wood immersed used the wooden stakes which were immersed in water for 48 hours at 45 days after the experiment was installed. It showed that C. gestroi consumed $(20.45 \pm 11.3 \mathrm{~g})$ of wooden stakes that were immersed in water for 48 hours. 
Table 2 - Subterranean termite consumption rates (g) for Pinus sp. wood immersed in water for $0,24,48$ and $72 \mathrm{~h}$, at 30,45 and 60 days after the installation of the experiment

Quadro 2 - Taxa de consumo (em gramas) de madeira de Pinus sp. imersa em água por 0, 24, 48 e 72 horas por térmitas subterrâneos, em 30, 45 e 60 dias após a instalação do experimento

\begin{tabular}{|c|c|c|c|}
\hline \multirow{2}{*}{$\begin{array}{c}\text { Time of } \\
\text { immersion of } \\
\text { stakes in water } \\
(\mathrm{h})\end{array}$} & \multicolumn{3}{|c|}{ Mean wood consumption rate /exposure period } \\
$(\mathrm{g} / \mathrm{day})^{1 /}$
\end{tabular}

1/ Averages within a column followed by the same letter are not significantly different, as gauged by Tukey's test $(\mathrm{P} \leq 0.05)$.

Table 3 - Subterranean termite consumption rates $(\mathrm{g})$ for wood immersed in water for $0,24,48$ and $72 \mathrm{~h}$, at 30 , 45 and 60 days after the installation of the experiment

ouadro 3 - Consumo (em gramas) de quatro espécies florestais por térmitas subterrâneos imersas em água por 0, 24, 48 e 72 horas em 30, 45 e 60 dias após a instalação do experimento

\begin{tabular}{|c|c|c|c|}
\hline \multirow{2}{*}{$\begin{array}{c}\text { Time of } \\
\text { immersion of } \\
\text { stakes in water } \\
(\mathrm{h})\end{array}$} & \multicolumn{3}{|c|}{ Wood consumption/exposure period (g/day $)^{1 /}$} \\
\cline { 2 - 4 } & 30 day & 45 day & 60 day \\
\hline 0 & $5.17 \mathrm{~b} \pm 11.3$ & $8.54 \mathrm{~b} \pm 11.3$ & $7.41 \mathrm{~b} \pm 11.3$ \\
\hline 24 & $4.95 \mathrm{~b} \pm 11.3$ & $3.43 \mathrm{~b} \pm 11.3$ & $4.59 \mathrm{~b} \pm 11.3$ \\
\hline 48 & $6.61 \mathrm{~b} \pm 11.3$ & $20.45 \mathrm{a} \pm 11.3$ & $3.26 \mathrm{~b} \pm 11.3$ \\
\hline 72 & $2.90 \mathrm{~b} \pm 11.3$ & $7.48 \mathrm{~b} \pm 11.3$ & $4.84 \mathrm{~b} \pm 11.3$ \\
\hline
\end{tabular}

1/ Averages within a column followed by the same letter are not significantly different, as gauged by Tukey's test $(\mathrm{P} \leq 0.05)$.

Laboratory studies conducted by Creffield et al. (1985) showed that the wood of Pinus radiata was more resistant to attack by $C$. acinaciformis than E. regnans during a period of 56 days. This termite species caused a mean percentage consumption of $58.26 \%$ in eucalyptus against $50.66 \%$ in pine. Conversely, in this study, the pine wood seemed to be more susceptible to attack by subterranean termites than eucalyptus wood. The highest mean percentage consumption rates recorded were ca. $3 \%$ to E. pellita, caused by $H$. longiceps at 30 days after the experiment was started, and $8.19 \%$ to E. urophylla, against $30.64 \%$ in Pinus sp. at 45 days by C. gestroi, although the mean percentage consumption of E. robusta caused by both $C$. havilandi and $N$. jaraguae was higher for the 60-day exposure period (32.55\%) (Figure 2). Strong differentiation in food choice exist between termite species. The separation of food niches prevents intraspecific competition for food and thus allows overlap of foraging territories. This could explain the highest consumption of E. robusta for the 60-day exposure period caused by $C$. gestroi and $N$. jaraguae in the same area.

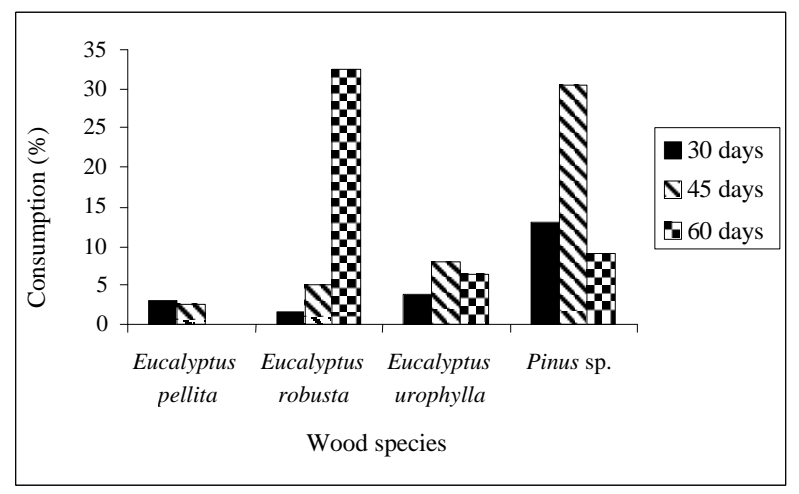

Figure 2 - Mean percentage wood consumption for the different forest species, caused by subterranean termites, over each field exposure period.

Figura 2 - Porcentagem média de perda de peso da madeira das diferentes espécies florestais causadas por térmitas subterrâneos, em cada período de exposição.

\section{CONCLUSIONS}

1. Although the wood-consumption rates of the forest species were not correlated significantly with their wood densities, there was a tendency for the softwoods (Eucalyptus robusta and Pinus sp.) to be more consumed by subterranean termites than the woods of intermediate hardness (Eucalyptus pellita and Eucalyptus urophylla).

2. Among the eucalyptus species, E. robusta was more consumed by subterranean termite than E. pellita and E. urophylla, indicating that the former is more susceptible to termite attack.

\section{ACKNOWLEDGMENTS}

We wish to thank Dr. R. Constantino (Universidade de Brasília, Department of Zoology, Brasília, DF) for identifying the termites.

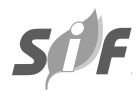




\section{REFERENCES}

ABREU, R. L. S.; SILVA, K. E. S. Resistência natural de dez espécies madereiras da Amazônia ao ataque de Nasutitermes macrocephalus (Silvestre) e N. surinamensis (Holmgren) (Isoptera: Termitidae). Revista Árvore, v. 24, p. 229-234, 2000.

ATKINSON, P. R; NIXON, K. M.; SHAW, M. J. P. On the susceptibility of Eucalyptus species and clones to attack by Macrotermes natalensis Haviland (Isoptera: Termitidae).

Forest Ecology and Management, v. 48, p. 15-30, 1992.

BEHR, E. A.; BEHR, C. T.; WILSON, L. F. Influence of wood hardness on feeding by the eastern subterranean termite, Reticulitermes flavipes (Isoptera: Rhinotermitidae). Annals of the Entomological Society of America, v. 65, p. 457-460, 1972.

BICALHO, A. C. Aspectos comportamentais, taxa de consumo e marcação do cupim subterrâneo Coptotermes havilandi Holmgren, 1911 (Isoptera: Rhinotermitidae) em área residencial. 2000. 82 f. Dissertação (Mestrado em Agronomia/Entomologia) - Universidade Federal de Lavras, Lavras, 2000.

BULTMAN, .D.; SOUTHWELL, C. R. Natural resistance of tropical American woods to terrestrial wood-destroying organism. Biotropica, v. 8, p. 71-95, 1976.

BULTMAN, .D.; BEAL, R. H.; AMPONG, F. F. K. Natural resistance of some tropical African woods to Coptotermes formosanus Shirak. Forest Products Journal, v. 29, p. 46-51, 1979.

CARTER, F. L.; SMYTHE, R. V. Feeding and survival responses of Reticulitermes flavipes (Kollar) to extractives of woods from 11 coniferous genera. Holzforschung, v. 28, p. 41-45, 1974.

CREFFIELD, J. W.; HOWICK C. D.; PAHL, P. J. Comparative wood consumption within and between mounds of Coptotermes acinaciformis (Froggatt) (Isoptera: Rhinotermitidae). Sociobiology, v. 11, p. 77-86, 1985.

CONSTANTINO, R. Key to the soldier of South American Heterotermes with a new species from Brazil (Isoptera:

Rhinotermititdae). Insect Systematics \& Evolution, v. 31, p. 463-472, 2001.

COULSON, R. N.; LUND, A. E. Degradation of wood by insects. In: NICHOLS, D. D. (Ed.) Wood deterioration and its prevention. New York: Syracuse University Press, 1973. p. 277-305.
FIDERJ. Indicadores climatológicos: sistema de informação para o planejamento estadual. Rio de Janeiro: FIDERJ/SECPLAN, 1976. $54 \mathrm{p}$.

GRACE, J. K. Influence of tree extractives on foraging preferences of Reticulitermes flavipes (Isoptera: Rhinotermitidae). Forestry Abstracts, v. 58, n. 12, abstract 987, p.1432, 1997.

LEMAIRE, M. et al. Geranyllinallol (diterpene alcohol). An insecticidae component of pine wood and termite (Isoptera: Rhinotermitidae) in four European ecosytems. Forestry Abstracts, v. 52, n. 12, Abstract 9177, p. 1291, 1991.

LENZ, M. Implication for comparability of laboratory experiments revealed in studies on the variability in survival and wood consumption between colonies of Coptotermes acinaciformis (Froggatt) (Isoptera: Rhinotermitidae). In: MEETING OF THE INTERNATIONAL RESEARCH GROUP ON WOOD PRESERVATION, 14., 1983, Surfers Paradise. Proceedings... Surfers Paradise: 1983. p. 1-6.

MALAN, F. S. The wood properties of South African grown Eucalyptus grandis. Some notes on their variation and association. Wood South Africa, v. 14, p. 61-67, 1989.

MELO, J. E.; CORADIN, V. T. R.; MENDES, J. C. Classes de densidades para madeiras da Amazônia brasileira. In: CONGRESSO FLORESTAL BRASILEIRO, 6., 1990, Campos do Jordão. Resumos... Campos do Jordão: SBS/ SBEF, 1990. p. 695-699.

NAGNAN, P.; CLEMENT, J. L. Terpenes from the maritime pine Pinus pinaster: toxins for subterranean termites of the genus Reticulitermes (Isoptera: Rhinotermitidae). Biochemical Systematics and Ecology, v. 18 , p. 13-16, 1990.

SCHEFFRAHN, R. H. Allelochemical resistance of wood to termites. Sociobiology, v. 1, n. 1, p. 257-281, 1991.

SKOLMEN, R. G. Natural durability of some woods used in Hawaii. Results of $91 / 2$ years' exposure, Berkeley: USDA Forest Service Research, 1974. 6 p. (Note PSW-292),

SMYTHE, R. V.; CARTER, F. L.; BAXTER, C. C. Influence of wood decay on feeding and survival of the eastern subterranean termite Reticulitermes flavipes (Isoptera: Rhinotermitidae). Ibid, v. 64, p. 59-62, 1971.

SPRINGHETTI, A.; AMORELLI, M. Competitive behavior between two species of Isoptera: Kalotermes flavicollis and Reticulitermes lucifugus. Sociobiology, v. 7, p. 155-164, 1982. 
SU, N. Y.; SCHEFFRAHN, R. H. Intra- and interspecific competition of the Formosan and eastern subterranean termite: evidence from field observations (Isoptera: Rhinotermitidae). Sociobiology, v. 14, p. 157-164, 1988.

THORNE, B. L. Termite-termite interations: workers as an agonistic caste. Psyche, v. 89, p. 133-150, 1982.
VITAL, B. R. Métodos de determinação da densidade da madeira. Viçosa: Sociedade Brasileira de Investigações Florestais/UFV, 1984. 19 p. (Boletim Técnico, 1).

WALLER, D. A.; JONES, C. G.; LA FAGE, J. P. Measuring wood preference in termites. Entomologia Experimentalis et Applicata, v. 56, p. 117-123, 1990. 